\title{
Relação Banco-Cliente como Relação Típica de Consumo
}

\author{
José Geraldo Brito Filomeno' \\ "Dai, pois, a César o que é de César [...]" \\ (Lucas 20,23)
}

Os meios de comunicação de massa têm dado destaque ao conflito entre o Código de Defesa do Consumidor e o chamado "Código de Defesa do Consumidor Bancário", notadamente após o ajuizamento da Ação Direta de Inconstitucionalidade no 2591-1 pela Confederação Nacional do Sistema Financeiro, em 2001, e julgada, finalmente, no dia 7 de junho de 2006, por esmagadora maioria. Ou seja, nove ministros, em última análise, ferindo diretamente o mérito da referida açāo, asseveraram que as relações de consumo de natureza bancária ou financeira devem ser protegidas pelo Código de Defesa do Consumidor.

Sob a argumentaçāo de que as relaçōes entre clientes e bancos devem ser reguladas, apenas, pelos órgãos competentes, a começar pelo Banco Central e pelo Conselho Monetário Nacional, a referida entidade promoveu a ação direta de inconstitucionalidade. Desta forma, seria "inconstitucional" o parágrafo $2^{\circ}$ do art. $3^{\text {}}$ do referido Código do Consumidor, que estabelece que "serviço é qualquer atividade fornecida no mercado de consumo, mediante remuneração, inclusive as de natureza bancária, financeira, de crédito e securitária, salvo as decorrentes das relaçôes de caráter trabalhista". ${ }^{2}$

JOSÉ GERALDO BRITO FILOMENO é atualmente advogado e consultor jurídico, especialista em Direito do Consumidor, gestor do curso de direito da Universidade de Mogi das Cruzes, campus "VillaLobos", na Capital de S. Paulo. É também professor, nível de pós-graduação, nas UNI-FMU de Direito do Consumidor. Foi Procurador-Geral de Justiça do Estado de S. Paulo (2000-2002) e um dos autores do anteprojeto de Código de Defesa do Consumidor.

2 A respeito do "conceito jurídico de banco", anota CELSO MARCELO DE OLIVEIRA (Código de defesa do cliente bancário, LZN Editora, Campinas, 2002, p. 15): "O conceito de banco é coincidente entre os autores, devido à atividade específica por eles desenvolvida. Carvalho de Mendonça define banco como sendo uma empresa comercial 'cujo objetivo principal consiste na intromissão entre os que dispōem de capitais e os que precisam obtê-los, isto é, em receber e concentrar capitais para, sistematicamente, distribuí-los por meio das operaçōes de crédito'. Neste sentido, temos inicialmente o mestre Fran Martins, que entende que os bancos são mais 
do que meros intermediários, sāo mobilizadores comerciais do crédito, mediante recebimento de capital de terceiros e empréstimo deste capital, em seu próprio nome, aos que dele necessitarem. Em síntese, o banco é definido como uma empresa comercial que capta poupança e a distribui sistematicamente através de operaçóes de crédito. Mais especificamente, o banco se utiliza de recursos de terceiros, ou próprios, na atividade crediticia de tomar e dar em empréstimo. O que releva da atividade bancária, para este trabalho, é a sua natureza comercial. A intensificação e a expansão da atuação bancária decorre do fato de que, invariavelmente, o desenvolvimento de atividades produtivas ou de consumo dependem de crédito, pois os agentes econômicos nem sempre possuem o montante financeiro suficiente para gerir seus negócios, expandir ou mesmo antecipar o consumo, buscando nas instituições financeiras recursos para alcançar seus objetivos. De acordo com a Lei Brasileira de Reforma Bancária (Lei $n^{\circ}$ 4.595/64), em seu art. 17: 'Sāo consideradas instituiçōes financeiras [...] aquelas entidades públicas e privadas que têm primária ou secundariamente as atividades de captação, o ato de intermediação (de recursos financeiros).' No mesmo sentido, o Manual de Nor mas e Instruçōes (MNI) do Banco Central do Brasil (BACEN), os bancos (comerciais) sāo intermediários financeiros que recebem o dinheiro do público e o emprestam àqueles que dele necessitam com o fim de multiplicar a circulação de moeda - o chamado 'efeito multiplicador da moeda'." Conforme anotamos em nosso Manual de direitos do consumidor (Editora Atlas, SP, 8. ed., p. 42-43: "Resta evidenciado, por outro lado, que as atividades desempenhadas pelas instituiçōes financeiras, quer na prestaçāo de serviços aos seus clientes (por exemplo, cobrança de contas de energia elétrica, água e outros serviços, ou então expediçāo de extratosavisos etc.), quer na concessão de mútuos ou financiamentos para a aquisiçāo de bens, inserem-se igualmente no conceito amplo de serviços e enquadram-se indubitavelmente nos dispositivos do novo Código de Defesa do Consumidor. Aliás, o mencionado código fala expressamente em atividades de natureza bancária, financeira, de crédito e securitária, ao definir 'serviços' de modo geral $\left(\$ 2^{\circ}\right.$ do art. $3^{\circ}$ ), aqui se incluindo, também, os planos de previdência privada em geral, além dos seguros propriamente ditos, e de qualquer natureza. Para Fábio Ulhôa Coelho (1994:174), 'considera-se bancário o contrato cuja função econômica se relaciona com o conceito juridico de atividade bancária, preceituado no art. 17 da Lei $n^{\circ} 4.595 / 64$; por atividade bancária entende-se a coleta, intermediaçāo em moeda nacional ou estrangeira; esse conceito abarca uma gama considerável de operações econômicas, ligadas direta ou indiretamente à concessão, circulação ou administração do crédito; estabelecendo-se paralelo entre a atividade bancária $e$ a industrial, pode-se afirmar que a matéria-prima do banco e o produto que ele oferece ao mercado é o crédito, ou seja, a instituição financeira dedica-se a captar recursos junto a clientes (operações passivas) para emprestá-los a outros clientes (operaçōes ativas)'. E, mais adiante, esclarece que 'o contrato bancário pode ou nāo se sujeitar ao Código de Defesa do Consumidor, dependendo da natureza do vínculo obrigacional subjacente; o mútuo, por exemplo, será mercantil se o mutuário for exercente de atividade econômica, e os recursos obtidos a partir dele forem empregados na empresa; e será mútuo ao consumidor se o mutuário utilizar-se dos recursos emprestados para finalidades particulares, como destinatário final; no desenvolvimento das operaçōes atípicas, isto é, não relacionadas especifícamente com o conceito de atividade bancária, como cobrança de títulos e recebimento de tarifas e impostos, o banco age como prestador de serviços não somente para o cliente credor, mas direcionado a todos que procuram a agência simplesmente para realizar o pagamento; em relação às operações típicas, como a aceitação de dinheiro em depósito, concessão de empréstimo bancário, aplicaçāo financeira e outras, o banco presta serviço a clientes seus, podendo classificá-los (de acordo com conceitos próprios da atividade bancária, como o da reciprocidade) para fins de liberar tratamento preferencial ou atendimento especial a certas categorias de consumidores'. Também José Reinaldo da Lima Lopes (1997:87) acentua que 'é fora de dúvida que os serviços financeiros, bancários e securitários encontram-se sob as regras do Código

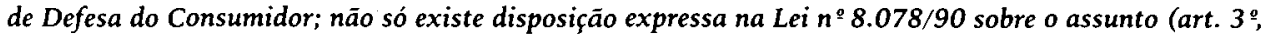
$\left.\$ 2^{\circ}\right)$, como a história da defesa do consumidor o confirma, quando verificamos que a proteçāo aos tomadores de crédito ao consumo foi das primeiras a ser criada; de outro lado, nas relações das instituições financeiras com seus 'clientes' podem-se ver duas categorias de agentes: os tomadores de empréstimos (mutuários) e os investidores (depositantes)'. Diante dessas ponderaçōes, por conseguinte, e conforme a síntese elaborada por Nélson Nery Jr. (1992:302-311), caracterizam-se os serviços bancários como relações de consumo em decorrência de quatro circunstâncias, a saber: (a) por 
Até porque, além da Lei no $4.595 / 64$, que regula o Sistema Financeiro Nacional, o art. 192 da Constituição Federal exige a edição de leis complementares, ainda não votadas pelo Congresso Nacional, que serão hierarquicamente superiores ao Código do Consumidor, Lei Ordinária (nº 8.078/90), para, em última análise, reorganizar o mesmo sistema, balizado pela nova ordem constitucional.

serem remunerados; (b) por serem oferecidos de modo amplo e geral, despersonalizado; (c) por serem vulneráveis os tomadores de tais serviços, na nomenclatura própria do CDC; (d) pela habitualidade e profissionalismo na sua prestação."

Também nesse sentido anota CELSO MARCELO DE OLIVEIRA, na obra retrocitada, p. 46-50: "Temos o pensamento de Ross Cranston: 'As atividades bancárias típicas - recebimento de depósitos e concessão de empréstimos - obviamente envolvem o fornecimento de um serviço. O cumprimento de um pagamento à ordem do consumidor é também um serviço. Igualmente, são os aconselhamentos financeiros, a atividade securitária, o gerenciamento de fundos de investimentos e assim por diante' [...] Assim também pensa Cláudia Limas Marques: 'Os contratos bancários atuais são contratos cativos de longa duração. Observadas as especialidades dos contratos bancários em questão, sob o signo da continuidade dos serviços, massificação e catividade dos clientes, da prestabilidade por terceiros de serviços autorizados ou controlados pelo Estado, do macro-interesse do verdadeiro objeto contratual, da internacionalidade ou grande poder econômico dos fornecedores. E acima de tudo, continuidade das relaçōes, tendo em vista a essencialidade do crédito na sociedade de consumo atual, concluiu-se que os modelos tradicionais de contrato (contratos envolvendo obrigaçōes de dar, imediatos e menos complexos) fornecem poucos instrumentos para regular estas longuíssimas, reiteradas e complexas relaçōes contratuais, necessitando, seja a intervençāo regulamentadora do legislador através do CDC para a proteção dos mais vulneráveis, seja a intervenção reequilibradora e sábia do Judiciário nos casos concretos.' Por conseguinte, o banco é, sim, fornecedor, seja de serviço, seja de bem, seja de ambos. Em complemento, temos Cláudio Bonatto e Paulo Valério Dal Pai Moraes: 'o CDC, de fato, se aplica aos contratos bancários, existindo, inclusive, jurisprudência do Tribunal de Alçada do Rio Grande do Sul reconhecendo tal aplicaçāo até para o caso em que sejam firmados por pessoas jurídicas'. Não há como deixar de registrar a manifestação do Dr. Otto Steiner Júnior, que, na condiçāo de representante da FEBRABAN (entidade associativa dos bancos brasileiros), em palestra proferida na Escola Superior da Magistratura da AJURIS durante o Curso de Atualizaçāo em Direito Civil para Magistrados, afirmou tratar-se a aplicação do CDC aos contratos bancários de questão indiscutível [...] A respeito da aplicação do Código de Defesa do Consumidor aos contratos bancários, é importante a visāo no direito comparado. Temos os ensinamentos de Thierry Boneau: 'Ce cadre subia nécessairement les influences du droit de la consommation. Em particulier, la prohibition des clauses abusives, dont la détermination relève, malgré lès textes, du pouvoir du juge, s'applique ou domaine bancaire.' No direito espanhol, temos Fernando Sanches Calero: '[...] la tan bien intencionada como deficiente Ley 26/1984, de 19 de Julio, de Defensa de los Consumidores y Usuarios, em su artículo 10, contiene manifestaciones que son aplicables sin duda a los contratos bancarios'. Finalmente, no direito argentino, temos Juan M. Farina: 'La tutela Del hombre común como cliente de una entidad bancaria surge como un capítulo especial dentro del derecho de protección al consumidor (en este sentido ver art. 36 de la ley 24.240)'". Mais recentemente, nós nos deparamos com interessante artigo publicado no jornal Folha de S. Paulo, sob o título "OS BANCOS E A INFLAÇÃO", de autoria de ROBERTO LUÍS TROSTER, que é doutor em economia pela USP, é o economista-chefe da FEBRABAN (Federação Brasileira das Associaçōes de Bancos) e professor titular do Departamento de Economia da PUC-SP, do qual extraímos o seguinte trecho: "Os bancos são essencialmente intermediários, que captam e emprestam recursos de terceiros. Sua matéria-prima é o dinheiro e a taxa de juros é o seu custo principal. Uma alta de juros tem o mesmo efeito que a alta de custo da matéria-prima da indústria ou do comércio. $O$ reflexo de uma alta de custos, quando a demanda permanece a mesma, é sempre um repasse parcial aos preços e uma perda de rentabilidade. Isso vale para a indústria, o comércio e os bancos." 
Para o ministro Cezar Peluso, ${ }^{3}$ o Código de Defesa do Consumidor não veio, contrariamente ao que afirmara a entidade autora da ação, para regular as relaçōes entre as instituiçōes do Sistema Financeiro Nacional e os clientes sob o ângulo estritamente financeiro, mas sim para dispor sobre as relações de consumo entre bancos e clientes. E nesse sentido ele argumentou que "não há como nem por onde sustentar, convincentemente, que o CDC teria derrogado, de forma inconstitucional, a Lei no 4.591/1964".

Também o ministro Marco Aurélio afirmou que o CDC não representa nenhum risco ao Sistema Financeiro Nacional (SFN) e destacou a crescente lucratividade dos estabelecimentos bancários para afastar o pensamento de que o CDC repercutiu de forma danosa em relação aos bancos.

Celso de Mello seguiu o entendimento da maioria pela improcedência do pedido na ação e ressaltou que a proteção ao consumidor qualifica-se como valor constitucional. Para o ministro, as atividades econômicas estão sujeitas à ação de fiscalização e normativa do Poder Público, pois o Estado é agente regulador da atividade negocial e tem o dever de evitar práticas abusivas por parte das instituiçōes bancárias. Nesse sentido, Celso de Mello entende que o Código de Defesa do Consumidor cumpre esse papel ao regulamentar as relações de consumo entre bancos e clientes. O ministro acrescentou que o Sistema Financeiro Nacional sujeita-se ao princípio constitucional de defesa do consumidor e que o CDC limita-se a proteger e defender o consumidor, "o que não implica interferência no SFN. Assim, concluiu que as regras do CDC aplicam-se às atividades bancárias".4

A última a votar, a presidente do STF, ministra Ellen Gracie, também entendeu que as relaçōes de consumo nas atividades bancárias devem ser protegidas pelo CDC. O placar do julgamento definitivo da ADI ficou da seguinte forma: pela improcedência do pedido formulado pela CONSIF, votaram os ministros Néri da Silveira, hoje aposentado, Eros Grau, Carlos Ayres Britto, Joaquim Barbosa, Sepúlveda Pertence, Cezar Peluso, Marco Aurélio, Celso de Mello e Ellen Gracie. Ficaram parcialmente vencidos os ministros Carlos Velloso (aposentado), como relator, e Nelson Jobim (também aposentado).

Quando Procurador-Geral de Justiça do Estado de São Paulo, aliei-me às entidades e juristas que, atuando como amici curiae, argumentando exatamente que uma coisa é o sistema financeiro nacional, disciplinado pela Lei no 4.595, de 1964 . Outra bem diversa é a relação banco-cliente. Até porque isso é expressamente previsto pelo $\$ 2^{\circ}$ do art. $3^{\circ}$ do Código de Defesa do Consumidor, além de se procurar proteger o vulnerável, em face do mais poderoso, por razōes óbvias, consoante dispõe o inciso I do art. $4^{\circ}$ do mesmo CDC. Além disso, acentuamos, na ocasião, que, hierarquia por hierarquia de normas, tanto o CDC como a "lei do sistema financeiro nacional", são leis ordinárias. E se assim fosse, então, pelo critério da superveniência de uma norma que tratasse de assuntos semelhantes, o CDC é que teria derrogado a "lei do sistema financeiro"!

Notícias do STF, no site <ww.stf.gov.br>.

4 Idem. 


\section{Por outro lado, diríamos desde logo que, na verdade, houve um falso debate acerca do aparente conflito entre as Resoluções Bacen $n^{\circ s} 2.878^{5} \mathrm{e}$}

5 A Resolução n’ 2.878 do Banco Central "dispōe sobre procedimentos a serem observados pelas instituiçōes financeiras e demais instituiçōes autorizadas a funcionar pelo Banco Central do Brasil na contratação de operaf̧ōes e na prestação de serviços aos clientes e ao público em geral" (destaque em negrito no original). Analisado o seu texto, verifica-se que seu art. $1^{\circ}$ estabelece uma série de principios, que de forma alguma destoam dos elencados pelo Código de Defesa do Consumidor. Ao contrário, reforçam esses mesmos princípios da ciência consumerista. Com efeito, deliberou-se o seguinte: "Art. $\mathbf{I}^{\text {o }}$ Estabelecer que as instituiçōes financeiras e demais instituições autorizadas a funcionar pelo Banco Central do Brasil, na contratação de operaçōes e na prestaçāo de serviços aos clientes e ao público em geral, sem prejuízo da observância das demais disposiçōes legais e regulamentares vigentes e aplicáveis ao Sistema Financeiro Nacional, devem adotar medidas que objetivem assegurar: $\boldsymbol{I}$ - transparência nas relações contratuais, preservando clientes $e$ o público usuário de práticas nāo eqüitativas, mediante prévio e integral conhecimento das cláusulas contratuais, evidenciando, inclusive, os dispositivos que imputem responsabilidades e penalidades; II - resposta tempestiva às consultas, às reclamaçōes e aos pedidos de informaçōes formulados por clientes e público usuário, de modo a sanar, com brevidade e eficiência, dúvidas relativas aos serviços prestados e/ou oferecidos, bem como às operações contratadas, ou decorrentes de publicidade transmitida por meio de quaisquer veículos institucionais de divulgação, envolvendo, em especial: a) cláusulas e condiçōes contratuais; b) características operacionais; c) divergências na execução dos serviços; III - clareza e formato que permitam fácil leitura dos contratos celebrados com clientes, contendo identificação de prazos, valores negociados, taxas de juros, de mora e de administraçāo, comissão de permanência, encargos moratórios, multas por inadimplemento e demais condiçōes; IV - fornecimento aos clientes de cópia impressa ou em meio eletrônico, dos contratos assim que formalizados, bem como recibos, comprovantes de pagamentos e outros documentos pertinentes às operaçōes realizadas; $\boldsymbol{V}$ - efetiva prevenção e reparação de danos patrimoniais $e$ morais, causados a seus clientes $e$ usuários. Art. $2^{\circ}$ As instituiçōes referidas no art. $1^{\circ}$ devem colocar à disposiçāo dos clientes, em suas dependências, informaçōes que assegurem total conhecimento acerca das situaçōes que possam implicar recusa na recepfão de documentos (cheques, bloquetos de cobrança, fichas de compensą̧ão e outros) ou na realizaçāo de pagamentos, na forma da legislaçāo em vigor. Parágrafo único. As instituiçōes referidas no caput devem afixar, em suas dependências, em local e formato visiveis, o número do telefone da Central de Atendimento ao Público do Banco Central do Brasil, acompanhado da observação de que o mesmo se destina ao atendimento a denúncias e reclamaçōes, além do número do telefone relativo ao serviço de mesma natureza, se por elas oferecido. Art. $3^{\circ}$ As instituiçôes referidas no art. $1^{\circ}$ devem evidenciar para os clientes as condições contratuais $e$ as decorrentes de disposiçōes regulamentares, dentre as quais: $I$ - as responsabilidades pela emissão de cheques sem suficiente provisão de fundos; II - as situaçōes em que o correntista será inscrito no Cadastro de Emitentes de Cheques sem Fundos (CCF); III - as penalidades a que o correntista está sujeito; IV - as tarifas cobradas pela instituição, em especial aquelas relativas a: a) devolução de cheques sem suficiente provisão de fundos ou por outros motivos; b) manutençāo de conta de depósitos; $V$ - taxas cobradas pelo executante de serviço de compensaçāo de cheques $e$ outros papéis; VI - providências quanto ao encerramento da conta de depósitos, inclusive com definição dos prazos para sua adoção; VII - remuneraçōes, taxas, tarifas, comissões, multas e quaisquer outras cobranças decorrentes de contratos de abertura de crédito, de cheque especial e de prestaçāo de serviços em geral. Parágrafo único. Os contratos de cheque especial, além dos dispositivos referentes aos direitos $e$ às obrigaçōes pactuados, devem prever as condiçōes para a renovação, inclusive do limite de crédito, e para a rescisāo, com indicação de prazos, das tarifas incidentes e das providências a serem adotadas pelas partes contratantes. Art. $4^{\circ}$ Ficam as instituiçóes referidas no art. $1^{\circ}$ obrigadas a dar cumprimento a toda informaçāo ou publicidade que veicularem, por qualquer forma ou meio de comunicação, referente a contratos, operaçōes e serviços oferecidos ou prestados, que devem inclusive constar do contrato que vier a ser celebrado. Parágrafo único. A publicidade de que trata o caput deve ser veiculada de tal forma que o público possa identificá-la de forma simples e imediata. Art. $5^{\circ} \dot{E}$ vedada às instituiçôes referidas no art. $1^{\circ}$, a utilização de publicidade enganosa ou abusiva. Parágrafo único. Para os efeitos do disposto no caput: $I$ - é enganosa qualquer modalidade de informação ou comunicą̧ão capaz de induzir a erro o cliente ou usuário, a respeito da natureza, características, riscos, taxas, comissóes, tarifas ou qualquer outra forma de remuneração, prazos, tributação e quaisquer outros dados referentes a contratos, operaçōes ou serviços oferecidos ou prestados; II - é abusiva, dentre outras, a publicidade que contenha discriminaçāo de qualquer natureza, que prejudique a concorrência ou que caracterize imposição ou coerçāo. Art. $6^{\circ}$ As instituiçōes referidas no art. $1 \stackrel{\circ}{\text {, sempre }}$ que necessário, inclusive por solicitação dos clientes ou usuários, devem comprovar a veracidade e a exatidâo da informaçāo divulgada ou da publicidade por elas patrocinada. Art. $7^{\circ}$ As instituiçōes referidas no art. $1^{\circ}$, na contratação de operações com seus clientes, devem assegurar o direito a liquidaçāo de operações com seus clientes, 
devem assegurar o direito a liquidação antecipada do débito, total ou parcialmente, mediante redução proporcional dos juros. Art. $8^{\circ}$ As instituiçōes referidas no art. $1^{\circ}$ devem utilizar terminologia que possibilite, de forma clara $e$ inequivoca, a identificação e o entendimento das operaçōes realizadas, evidenciando valor, data, local e natureza, especialmente nos seguintes casos: I - tabelas de tarifas de serviços; II - contratos referentes a suas operaçōes com clientes; III - informativos e demonstrativos de movimentação de conta de depósitos de qualquer natureza, inclusive aqueles fornecidos por meio de equipamentos eletrônicos. Art. $9^{\circ}$ As instituições referidas no art. $1^{\circ}$ devem estabelecer em suas dependências alternativas técnicas, fisicas ou especiais que garantam: I - atendimento prioritário para pessoas portadoras de deficiência fisica ou com mobilidade reduzida, temporária ou definitiva, idosos, com idade igual ou superior a sessenta e cinco anos, gestantes, lactantes e pessoas acompanhadas por criança de colo, mediante: a) garantia de lugar privilegiado em filas; $b$ ) distribuição de senhas com numeração adequada ao atendimento preferencial; c) guichê de caixa para atendimento exclusivo; ou d) implantação de outro serviço de atendimento personalizado; II - facilidade de acesso para pessoas portadoras de deficiêricia fisica ou com mobilidade reduzida, temporária ou definitiva, observado o sistema de segurança previsto na legislação e regulamentação em vigor; III - acessibilidade aos guichês de caixa e aos terminais de auto atendimento, bem como facilidade de circulaçâo para as pessoas referidas no inciso anterior: $I V$ - prestaçāo de informaçōes sobre seus procedimentos operacionais aos deficientes sensoriais (visuais e auditivos). $\$ 1^{\circ}$ Para fins de cumprimento do disposto nos incisos II e III, fica estabelecido prazo de 720 dias, contados da data da entrada em vigor da regulamentaçāo da Lei $n^{\circ} 10.098$, de 19 de dezembro de 2000, às instituições referidas no art. $1^{\circ}$, para adequação de suas instalações. $\mathbb{} 2^{\circ} \mathrm{O}$ início de funcionamento de dependência de instituiçāo financeira fica condicionado ao cumprimento das disposiçôes referidas nos incisos II e III, após a regulamentação da Lei n ${ }^{\circ} 10.098$, de 2000. Art. 10. Os dados constantes dos cartóes magnéticos emitidos pelas instituiçōes referidas no art. $1^{\circ}$ devem ser obrigatoriamente impressos em alto relevo, para portadores de deficiência visual. Art. 11. As instituições referidas no art. $1^{\circ}$ não podem estabelecer, para portadores de deficiência e para idosos, em decorrência dessas condiçōes, exigências maiores que as fixadas para os demais clientes, excetuadas as previsões legais. Art. 12. As instituį̧̃es referidas no art. $1^{\circ}$ não podem impor aos deficientes sensoriais (visuais e auditivos) exigências diversas das estabelecidas para as pessoas não portadoras de deficiência, na contratação de operaçōes e de prestação de serviços. Parágrafo único. Com vistas a assegurar o conhecimento pleno dos termos dos contratos, as instituiçôes devem: $\boldsymbol{I}$ - providenciar, no caso dos deficientes visuais, a leitura do inteiro teor do contrato, em voz alta, exigindo declaração do contratante de que tomou conhecimento de suas disposiçōes, certificada por duas testemunhas, sem prejuizo da adoção, a seu critério, de outras medidas com a mesma finalidade; 11 - requerer, no caso dos deficientes auditivos, a leitura, pelos mesmos, do inteiro teor do contrato, antes de sua assinatura. Art. 13. Na execuçâo de serviços decorrentes de convênios, celebrados com outras entidades pelas instituiçôes financeiras, é vedada a discriminação entre clientes e não-clientes, com relação ao horário e ao local de atendimento. Parágrafo único. Excetuam-se da vedação de que trata o caput: $I$ - o atendimento prestado no interior de empresa ou outras entidades, mediante postos de atendimento, ou em instalações não visiveis ao público; II - a fixaçāo de horários específicos ou adicionais para determinados segmentos e de atendimento separado ou diferenciado, inclusive mediante terceirizaçäo de serviços ou sua prestação em parceria com outras instituiçōes financeiras, desde que adotados critérios transparentes. Art. 14. É vedada a adoçāo de medidas administrativas relativas ao funcionamento das dependências das instituiçōes referidas no art. 1 'que possam implicar restriçōes ao acesso às áreas destinadas ao atendimento ao público. Art. 15. Ás instituiçōes referidas no art. $1^{\circ}$ é vedado negar ou restringir, aos clientes e ao público usuário, atendimento pelos meios convencionais, inclusive guichês de caixa, mesmo na hipótese de atendimento alternativo ou eletrônico. $\$ 1^{\circ} \mathrm{O}$ disposto no caput não se aplica às dependências exclusivamente eletrônicas. $\$ 2^{\circ}$ A presta̧̧ão de serviços por meios alternativos aos convencionais é prerrogativa das instituições referidas no caput, cabendo-lhes adotar as medidas que preservem a integridade, a confiabilidade, a segurança e o sigilo das transações realizadas, assim como a legitimidade dos serviços prestados, em face dos direitos dos clientes e dos usuários, devendo, quando for o caso, informá-los dos riscos existentes. Art. 16. Nos saques em espécie realizados em conta de depósitos à vista, na agência em que o correntista a mantenha, é vedado às instituições financeiras estabelecer prazos que posterguem a operação para o expediente seguinte. Parágrafo único. Na hipótese de saques de valores superiores a $R \$ 5.000$ (cinco mil reais), deve ser feita solicitaçāo com antecedência de quatro horas do encerramento do expediente, na agência em que o correntista mantenha a conta sacada. Art. 17. É vedada a contratação de quaisquer operaçōes condicionadas ou vinculadas à realização de outras operações ou à aquisição de outros bens e serviços. $1^{\circ}$ A vedação de que trata o caput aplica-se, adicionalmente, às promoçōes e ao oferecimento de produtos e serviços ou a quaisquer outras situaçōes que impliquem elevação artificiosa do preço ou das taxas de juros incidentes sobre a operą̧ão de interesse do cliente. $\$ 2^{\circ} \mathrm{Na}$ hipótese de operaçấo que implique, por força de contato e da legislação em vigor, pacto adicional de outra operação, fica assegurado ao contratante o direito de livre escolha da instituição com a qual deve ser formalizado referido 


\subsection{2/20016 (o tal “Código de Defesa do Consumidor Bancário"), de um lado, e o Código (verdadeiro) de Defesa do Consumidor, de outro.}

contrato adicional. $\varsigma^{\circ} \mathrm{O}$ disposto no caput nāo impede a previsão contratual de débito em conta de depósitos como meio exclusivo de pagamento de obrigações. Art. 18. Fica vedado às instituiçōes referidas no art. $1 \stackrel{\circ}{1} I-$ transferir automaticamente os recursos de conta de depósitos à vista e de conta de depósitos de poupança para qualquer modalidade de investimento, bem como realizar qualquer outra operação ou prestação de serviço sem prévia autorização do cliente ou do usuário, salvo em decorrência de ajustes anteriores entre as partes; II - prevalecer-se, em razão de idade, saúde, conhecimento, condição social ou econômica do cliente ou do usuário, para impor-lhe contrato, cláusula contratual, operação ou prestaçāo de serviço; III - elevar, sem justa causa, o valor das taxas, tarifas, comissões ou qualquer outra forma de remuneração de operações ou serviços ou cobrá-las em valor superior ao estabelecido na regulamentaçāo e legislaçāo vigentes; IV - aplicar fórmula ou índice de reajuste diverso do legal ou contratualmente estabelecido; $V$ - deixar de estipular prazo para o cumprimento de suas obrigaçōes ou deixar a fixaçāo do termo inicial a seu exclusivo critério; VI - rescindir, suspender ou cancelar contrato, operação ou serviço, ou executar garantia fora das hipóteses legais ou contratualmente previstas; VII - expor, na cobrança da dívida, o cliente ou o usuário a qualquer tipo de constrangimento ou de ameaça. $\$^{\circ} \mathrm{A}$ autorização referida no inciso I deve ser fornecida por escrito ou por meio eletrônico, com estipulą̧āo de prazo de validade, que poderá ser indeterminado, admitida a sua previsão no próprio instrumento contratual de abertura da conta de depósitos. $\$ 2{ }^{\circ} \mathrm{O}$ cancelamento da autorização referida no inciso I deve surtir efeito a partir da data definida pelo cliente, ou na sua falta, a partir da data do recebimento pela instituição financeira do pedido pertinente. $\$ 3^{\circ}$ No caso de operação ou serviço sujeito a regime de controle ou de tabelamento de tarifas ou de taxas, as instituiçōes referidas no art. $1^{\circ}$ não podem exceder os limites estabelecidos, cabendo-lhes restituir as quantias recebidas em excesso, atualizadas, de conformidade com as normas legais aplicáveis, sem prejuízo de outras sançōes cabiveis. $\$ 4^{\circ}$ Excetuam-se das vedaçōes de que trata este artigo os casos de estorno necessários à correção de lançamentos indevidos decorrentes de erros operacionais por parte da instituiçāo financeira, os quais deverāo ser comunicados, ao cliente, no prazo de até dois dias úteis após a referida correção. Art. 19. O descumprimento do disposto nesta Resoluçāo sujeita a instituição e os seus administradores às sançöes previstas na legislação e regulamentação em vigor. Art. 20. Fica o Banco Central do Brasil autorizado a: I - baixar as normas e a adotar as medidas julgadas necessárias à execuçāo do disposto nesta Resolução, podendo inclusive regulamentar novas situaçōes decorrentes do relacionamento entre as pessoas fisicas e jurídicas especificadas nos artigos anteriores; II - fixar, em razāo de questöes operacionais, prazos diferenciados para o atendimento do disposto nesta Resoluçāo. Art. 21. Esta Resolução entra em vigor na data de sua publicaçāo. Art. 22. Ficam revogados o \& $2^{\circ}$ do art. $1^{\circ}$ da Resoluçāo $n^{\circ} 1.764$, de 31 de outubro de 1990, com redação dada pela Resolução nº 1.865, de 5 de setembro de 1991, a Resolução n².411, de 31 de julho de 1997, e o Comunicado n' 7.270, de 9 de fevereiro de 2000. Brasília, 26 de julho de 2001. Carlos Eduardo de Freitas - Presidente Interino."

6 RESOLUÇÃO № 2.892/2001 - "O Banco Central do Brasil e o Conselho Monetário Nacional em 27 de setembro de 2001 efetuaram a primeira alteração no teor jurídico contido na RESOLUÇĀO $n^{2}$ 2.878/2001. Diante disto se faz por necessário uma apreciaçāo do teor da Resoluçāo $n^{\circ} 2.878$, de 2001, que dispōe sobre procedimentos a serem observados pelas instituiçōes financeiras e demais instituiçōes autorizadas a funcionar pelo Banco Central do Brasil na contratação de operaçōes e na prestaçāo de serviços aos clientes e ao público em geral: Art. 1 - Alterar os dispositivos abaixo especificados da Resolução $n^{\circ} 2.878$, de 26 de jultho de 2001, que passam a vigorar com a seguinte redaçāo: 1 - 0 art. $1^{\circ}$, inc. IV - Art. $1^{\circ}$ Estabelecer que as instituiçōes financeiras e demais instituiçōes autorizadas a funcionar pelo Banco Central do Brasil, na contrataçāo de operaçōes e na prestação de serviços aos clientes e ao público em geral, sem prejuízo da observância das demais disposiçôes legais e regulamentares vigentes e aplicáveis ao Sistema Financeiro Nacional, devem adotar medidas que objetivam assegurar: $I V$ - fornecimento aos clientes de cópia impressa, na dependência em que celebrada a operação, ou em meio eletrônico, dos contratos, após formalização e adoção de outras providências que se fizerem necessárias, bem como de recibos, comprovantes de pagamentos e outros documentos pertinentes às operaçôes realizadas; $I I-o$ art. $2^{\circ}:$ Art. $2^{\circ}$ As instituiçães referidas no art. Iํ. devem colocar à disposição dos clientes, em suas dependências e nas dependências dos estabelecimentos onde seus produtos forem negociados, em local e formato visiveis: $I$ - informaçōes que assegurem total conhecimento acerca das situações que possam implicar recusa na recepção de documentos (cheques, bloquetos de cobrança, fichas de compensação e outros) ou na realizaçâo de pagamentos, na forma de legislação em vigor; II - o número do telefone da Central de Atendimento ao Público do Banco Central do Brasil, acompanhado da observaçāo de que o mesmo se destina ao atendimento a denúncias e reclamaçōes, além do número do telefone relativo a serviço de mesma natureza, se por elas oferecido; III - as informaçōes estabelecidas pelo art. $2^{\circ}$ da Resolução $n^{\circ}$ 2.303, de 25 de julho de 1996. III - o art. $7^{\circ}$ : Art. $7^{\circ}$ As instituiçōes referidas no art. $1 \stackrel{\circ}{\circ}$ nas operaçōes de crédito 
E isto porque, enquanto o Código do Consumidor regula as relações de consumo, aí se incluindo, no que concerne ao sistema financeiro, por exemplo, as ofertas de crédito, publicidade de bancos, contratos (sempre de adesāo, em que as cláusulas são previamente elaboradas por eles mesmos) e práticas comerciais, de modo geral as resoluções mencionadas, assim como outras, editadas pelo Banco Central do Brasil, revelam, na verdade, uma vontade de tornar mais transparentes as relações banco-cliente e, mais especificamente, traçar normas de conduta, infraçōes administrativas e conseqüentes punições, estabelecer tarifas e seus limites, horários de atendimento, tratamento especial a idosos e deficientes etc.

Desta forma, diríamos que tanto o Código do Consumidor como as Resoluções do Banco Central visam a um mesmo desiderato, qual seja, e num primeiro aspecto, a defesa do consumidor. Só que o Banco Central exerce o que se chama "poder de polícia administrativa", dentro das atividades que regulamenta e disci-

pessoal e de crédito pessoal e de crédito direto ao consumidor, realizadas com seus clientes, devem assegurar o direito à liquidação antecipada do débito total ou parcialmente, mediante redução proporcional dos juros. $I V-o$ art. 10: Art. 10. os dados constantes dos cartões magnéticos emitidos pelas instituiçôes referidas no art. $1^{\circ}$ devem ser obrigatoriamente impressos em alto relevo, para portadores de deficiência visual. $V$-o art. 12, parágrafo único, inc. I: Art. 12. As instituiçöes referidas no art. $1^{\circ}$ nāo podem impor aos deficientes sensoriais (visuais e auditivos) exigências diversas das estabelecidas para as pessoas não portadoras de deficiência, na contrataçāo de operaçōes $e$ de prestação de serviços. Parágrafo único. Com vistas a assegurar o conhecimento pleno dos termos dos contratos, as instituiçōes devem: I - providenciar, na assinatura de contratos com portadores de deficiência visual, a não ser quando por eles dispensadas, a leitura do inteiro teor do referido instrumento, em voz alta, exigindo, mesmo no caso de dispensa da leitura, declaraçāo do contratante de que tomou conhecimento dos direitos e deveres das partes envolvidas, certificada por duas testemunhas, sem prejuizo da adoção, a seu critério, de outras medidas com a mesma finalidade; VI-o art. 14: Art. 14. É vedada a adoção de medidas administrativas relativas ao funcionamento das dependências das instituiçōes referidas no art. $I^{\circ}$ que possam implicar restriçōes ao acesso às áreas destinadas ao atendimento ao público; VII - o art. 16: Art. 16. Nos saques em espécie, de valores acima de $R \$ 5.000,00$ (cinco mil reais), realizados em conta de depósitos à vista, as instituiçōes poderão postergar a operação para o expediente seguinte, vedada a utilização de tal faculdade nos saques de valores inferiores ao estabelecido; VIII - o art. 17, $\int 22^{\circ}$ Art. 17. É vedada a contratação de quaisquer operaçōes condicionadas ou vinculadas à realizaçāo de outras operaçōes ou à aquisiçāo de outros bens e serviços. $\ 2^{\circ} \mathrm{Na}$ hipótese de operação que implique, por força de contrato e da legislação em vigor, pacto adicional de outra operação, fica assegurado ao contratante o direito de livre escolha da instituição com a qual deve ser formalizado referido contrato adicional. IX - o art. 18, $\$ 4^{\circ} \mathrm{Art}$. 18. Fica vedado às instituiçöes referidas no art. $1 \stackrel{\circ}{:} \$ 4^{\circ}$ Excetuam-se das vedaçōes de que trata este artigo os casos de estorno necessários à corrę̧āo de lançamentos indevidos decorrentes de erros operacionais por parte da instituição financeira, os quais deverão ser comunicados ao cliente, no prazo de até dois dias úteis após a referida correção. Art. $2^{\circ}$ Ficam as instituiçōes financeiras e demais instituiçōes autorizadas a funcionar pelo Banco Central do Brasil obrigadas a exigir de seus clientes e usuários confirmação clara e objetiva quanto a aceitaçāo do produto ou serviço oferecido ou colocado à sua disposiçāo, não podendo considerar o silêncio dos mesmos como sinal de concordância. Art. $3^{\circ}$ Ficam as instituiçōes referidas no artigo anterior obrigadas a garantir a seus clientes o cancelamento da autorizaçāo de débitos automáticos em conta efetuados por força de convênios celebrados com concessionários de serviço público ou empresa privada ou por iniciativa da própria instituiçāo, desde que, nesta hipótese, não decorram de obrigaçōes referentes a operaçōes de crédito contratadas com a própria instituição financeira. Parágrafo único - As instituiçôes referidas no caput têm prazo de até sessenta dias para adoção das providências necessárias à adequaçāo dos convênios celebrados, com vistas ao cumprimento do disposto neste artigo, mediante o estabelecimento de cláusula contratual específica. Art. $4^{\circ}$ Fica instituido o Manual do Cliente e Usuário de Serviços Financeiros e de Consórcio, que deverá consolidar as disposiçōes constantes da Resolução $n^{\circ}$ 2.878, de 2001 e desta resolução, além de outras estabelecidas em normativos editados pelo Banco Central do Brasil,

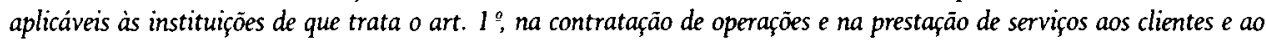
público em geral. Parágrafo único - O Banco Central do Brasil deve manter permanentemente atualizado o manual de que trata este artigo. Art. $5^{\circ}$ Esta Resolução entra em vigor na data de sua publicação. Brasília, 27 de setembro de 2001 - ARMINIIO FRAGA NETO - Presidente." 
plina, e aqui tomado no seu mais amplo sentido, conforme previsto pelo art. 78 do Código Tributário Nacional. ${ }^{7}$ Já o Código do Consumidor estabelece tutelas administrativa, civil e penal do mesmo consumidor, partindo do pressuposto de que ele é vulnerável e sujeito a toda sorte de abusos no mercado de produtos e serviços. No que diz respeito à tutela administrativa, compete, precipuamente, ao Banco Central, estabelecer normas de conduta dos estabelecimentos de crédito e respectivas sanções no caso de sua violaçāo. Isto é exercício de "polícia administrativa", da mesma forma que os órgãos de vigilância sanitária o exercem, por exemplo, em matéria de medicamentos, alimentos, e outros produtos ou serviços relacionados à saúde, retirando-os do comércio, quando apresentam alguma irregularidade, ou multando seus responsáveis. Se é certo que o Código do Consumidor, regulamentado pelo Decreto Federal $n^{\circ}$ 2.181/97, estabeleceu, também, uma tutela administrativa, na área específica de defesa do consumidor, fazem-no naquilo, apenas, que nāo é privativo dos órgãos de polícia administrativa (no caso, frise-se, o Banco Central), como nos exemplos acima citados, de práticas comerciais abusivas, publicidade enganosa, cláusulas abusivas em contratos de adesão etc. Nesses casos, aliás, além de sanções administrativas previstas pelo mencionado Decreto $n^{\circ} 2.181 / 97$, cabem açōes individuais ou coletivas (tutela civil), com vistas à adequação dos contratos e práticas aos postulados do Código do Consumidor, pagamento de indenizações por danos materiais e morais sofridos pelos consumidores e outras medidas reparatórias. No que diz respeito à tutela penal, constituem, por exemplo, conforme previsto pela "lei de crimes contra a economia popular" (Lei $n^{0} 1.521 / 51$ ), crimes de usura real e pecuniária a cobrança de juros e outros encargos acima dos legalmente permitidos, bem como o lucro excessivo, obtido através de engodos em contratos. Desta forma, os limites traçados pelas normas devem levar em conta as missões de cada ente público na defesa dos interesses dos consumidores. Como conclui a fábula de APELES, "que o sapateiro remendão não vá além das sandálias!".

Agora, dizer-se que o tal Código de Defesa do Consumidor Bancário é "superior" ao Código de Defesa do Consumidor de verdade, ou o "revogou", constitui um disparate.

Da mesma maneira, é um despropósito, com o devido respeito aos que assim não pensam, que o Código do Consumidor, "por ser lei ordinária”, não pode prevalecer sobre "uma lei complementar". Mas que lei complementar é essa, se o Congresso Nacional, após quase 14 anos da promulgação da Constituição de 1988, ainda nāo regulamentou o seu art. 192? Por outro lado, observa-se que todos os dispositivos desse artigo, à exceção do seu parágrafo $3^{\circ}$, que fala da limitação dos juros reais, aí incluídas comissōes e quaisquer

"Considera-se poder de polícia a atividade da administração pública que, limitando ou disciplinando direito, interesse ou liberdade, regula a prática de ato ou abstenção de fato, em razão de interesse público concernente à segurança, à higiene, à ordem, aos costumes, à disciplina da produçāo e do mercado, ao exercício de atividades econômicas dependentes de concessāo ou autorizaçaáo do Poder Público, à tranqüilidade pública ou ao respeito à propriedade e aos direitos individuais ou coletivos." 
outras remuneraçōes direta ou indiretamente referidas à concessão de crédito, os quais não poderão ser superiores a doze por cento ao ano, caracterizando sua cobrança acima desse limite crime de usura, sāo normas realmente programáticas e suscetíveis de regulamentação. E isto pelo seguinte raciocínio, que nos parece claríssimo: se a Lei n⿳ $4.595 / 64$, ordinária, que, como visto, regulamentou o sistema financeiro nacional, derrogou o Decreto $n^{\circ} 22.626 / 33$, que estabelecera exatamente a regra repetida pela Constituição de 1988 , decreto esse que, por sua vez, havia determinado que os juros reais anuais, que pelo Código Civil de 1917 não poderiam ser superiores a seis por cento, pudessem chegar até os doze por cento ali mencionados, ou a Constituição "vale menos" do que a Lei $\mathrm{n}^{\mathrm{0}} 4.595 / 64$, ou a norma é auto-aplicável. Ou, por outro lado, teria havido o fenômeno da repristinação do Decreto n²22.626/33, já que o $\$ 3^{0}$ do art. 192 da Constituição Federal diz, mais resumidamente, apenas, exatamente o ali contido. Em conclusão: (a) não há como abstrair a atividade financeira do Código do Consumidor por expressa determinação legal e pela praxe mundial na tutela do consumidor; (b) lei ordinária ( $n^{0}$ 4.595/64 - lei do sistema financeiro) por lei ordinária ( $n^{\circ} 8.078 / 90$ - Código do Consumidor); partindo-se da premissa de que a lei anterior é derrogada pela posterior, expressa ou implicitamente, se incompatíveis alguns dos ditames de uma e outra, deve prevalecer o Código do Consumidor; (c) o parágrafo $3^{\circ}$ do art. 192 da Constituição Federal, ao par de ser auto-aplicável, já que estabelece até percentual máximo da taxa de juros, $\mathrm{e}^{8}$ complementa a "lei de crimes contra a eco-

\footnotetext{
8 A jurisprudência nacional, aliás, na aplicaçāo dos preceitos mencionados, tem maciçamente reconhecido as atividades bancárias como relaçōes de consumo. Com efeito, o Superior Tribunal de Justiça assim já se manifestou a respeito: "Os Bancos como prestadores de serviços especialmente contemplados no artigo 3\%, parágrafo segundo, estāo submetidos às disposiçōes do Código de Defesa do Consumidor"; "As instituições financeiras estāo sujeitas à disciplina do CDC"; "e "Código de Defesa do Consumidor. Atividade bancária. Sujeição aos seus preceitos". E, no mesmo sentido: "A atividade bancária está sujeita à disciplina que rege as relaçōes de consumo"; "Os Bancos como prestadores de serviços estão submetidos às disposiçōes do Código de Defesa do Consumidor"; "As instituiçôes financeiras estão sujeitas ao CDC". No que tange aos sujeitos ou partes envolvidos nos contratos bancários, assim se manifestou o então Tribunal de Alçada do Rio Grande do Sul: "As instituições financeiras estão submetidas à disciplina do CDC quando o financiamento for realizado com pessoa fisica"; ou, ainda: "Entre o Banco e o cliente há relaçāo de consumo. Submissão ao CDC". Também o Tribunal de Justiça do referido Estado assim decidiu a matéria:

"A natureza da relação entre a instituição financeira e seu cliente, relativa à concessāo de crédito é de consumo, sujeitando-se aos ditames do Código." CONFIRAM-SE, RESPECTIVAMENTE: Recurso Especial n² 57.974-0, relator o ministro Ruy Rosado de Aguiar, julgamento de 25-4-95, votaçāo unânime. Recurso Especial $n^{\circ}$ 163.616-RS, relator o ministro Ruy Rosado de Aguiar, julgamento de 21-5-98, votação unânime. Agravo Regimental no Agravo n ${ }^{9}$ 49.124-2-RS, relator o ministro Ruy Rosado de Aguiar, julgamento de 4-10-94, votaçāo também unânime. Cfr., também, o Recurso Especial $n^{2} 213.825$, entendeu-se que o código do consumidor aplica-se às operaçōes bancárias, sobretudo no caso concreto, envolvendo financiamento para a compra de casa própria. O Ministro CÉSAR ROCHA, ao acompanhar o voto vencedor do relator, manifestou-se da seguinte maneira: "OCDC incide sobre todas as relaçōes e contratos pactuados pelas instituições financeiras e seus clientes, e não apenas na parte relativa à expedição de talonários, fornecimento de extratos, cobrança de contas, guarda de bens e outros serviços afins. As relaçōes existentes entre os clientes e o banco apresentam nítidos contornos de uma relaçāo de consumo." O pedido do banco em questão para elevar a taxa dos juros moratórios também foi rejeitado pelo relator, com base no Decreto ${ }^{2}$ $22.626 / 33$, permanecendo a taxa de $1 \%$ ao ano. $O$ recurso do banco foi acolhido apenas com relação aos juros remuneratórios. O Ministro BARROS MONTEIRO concluiu que a correção prevista
} 
nomia popular", notadamente a alínea "a" do seu art. $4^{\circ}$, caso típico de norma penal em branco, repristinou o Decreto $n^{0} 22.626 / 33 .{ }^{9}$ O mais, é má-vontade,

no acórdão - $14,93 \%$ ao ano - é válida. O relator lembrou a jurisprudência já consolidada pelo STJ e pelo STF, afirmando que a "Lei de Usura" - que limitaria a taxa de juros a $12 \%$ ao ano - nāo seria aplicável às operaçōes das instituiçōes financeiras: "A Suprema Corte assentou que os percentuais das taxas de juros se sujeitam unicamente aos limites fixados pelo Conselho Monetário Nacional." Apelação n 737.4107, $1^{\circ}$ Tribunal de Alçada Civil do Estado de S. Paulo, relatora a juíza Maria da Cunha, julgamento de 8-6-98, por votação unânime. Apelação Cível n² 177/94, do Tribunal de Justiça da Bahia, tendo por relator o desembargador Luís Pedreira Fernandes, julgamento de 14-4-97, votação unânime. Apelação Cível $n^{2}$ 197.144.595, do Tribunal de Alçada do Rio Grande do Sul, relator o juiz José Aquino Flores de Camargo, julgamento de 4-12-97, maioria de votos. Em sentido contrário, confira-se a Apelaçāo Cível $\mathrm{n}^{\mathrm{g}}$ 877.727-1, da Comarca de S. Faulo. A 6 Câmara do $1^{\circ}$ Tribunal de Alçada Civil do Estado de S. Paulo decidiu pela inaplicabilidade do art. 52, parágrafo $1^{\circ}$, da Lei $n^{\circ}$ 8.078/90 aos mútuos bancários, devido à inexistência de relaçāo de consumo a ser protegida. Vide, a seguir, trecho do acórdāo proferido: "Na verdade, não se aplica ao débito aqui questionado as regras do Código de Defesa do Consumidor, particularmente a do artigo 52, parágrafo I $\frac{\circ}{2}$ da Lei $n^{\circ} 8.078 / 90$, com a redação dada pela Lei $n^{\circ}=9.298 / 96$. É que as disposiçōes do referido diploma legal somente ganham incidência no respeitante aos serviços prestados por estabelecimentos bancários, instituiçōes ou empresas, mas não quando sejam concernentes ao sistema financeiro de crédito ou de seguros, na medida em que o campo normativo que se aplica a tal segmento, a norma constitucional privilegiou, como regente, a lei complementar, conforme regra estampada no artigo $192 \mathrm{da}$ Constituiçäo Federal. Assim, o perfil financeiro, creditício ou securitário do serviço qualifica a não aplicabilidade da norma do artigo 52, parágrafo 1 , da lei regencial da matéria, que não irradia, portanto, eficácia de incidencia. Não existe, pois, relação de consumo a ser protegida, senäo nas hipóteses em que os serviços sejam pagos ao banco, dos quais a empresa bancária se defina como fornecedora-credora e o cliente como interessado-devedor (cobrança de títulos, remessas de dinheiro, ordens de pagamento, consulta em terminais, administração de fundos ou de patrimônio, ad exemplum.) $O$ banco é um intermediário na circulação de dinheiro. Assim, ao tornarem-se devedores do agravante os agravados não se utilizaram de um serviço bancário. Nem adquiriram, naturalmente, qualquer produto, observado o sentido legal" (relator juiz EVALDO VERÍSSIMO). Apelação Cível nº 196.218.911, relator o juiz Silvestre Jasson Ayres Torres, julgamento de 12-12-96, por votação unânime. Com relação à discussāo sobre considerar-se a pessoa jurídica como consumidora de produtos e serviços, hipótese, a nosso ver, restrita à sua condição de hipossuficrente e/ou destinatária final de produtos e serviços, não utilizados profissionalmente, confira-se nosso Manual de direitos do consumidor, Sāo Paulo: Atlas, 3. ed., p. 33. Apelação Cível nº 196.049.514, relator o juiz Cláudio Caldeira Antunes, julgamento de 26-6-96. E, no mesmo sentido, confiram-se outros acórdãos do mesmo tribunal gaúcho: Apelaçōes n⿳; ${ }^{\circ}$; 196.094.403, de 19-9-96, 196.162.853, de 12-12-96, 196.197.115, de 10-6-97, 196.067.151, de 24-10-96, 193.051.216, 196.022.982, de 20-6-96, 196.117.337, de 11-9-96, e 196.128.821, de 29-8-96. Apelação Cível nº 597.106.533, relator o desembargador Arnaldo Rizzardo, julgamento de 3-9-97, por votaçāo unânime.

9 Para GUILHERME FERREIRA DA CRUZ, entretanto, que escreveu interessante artigo intitulado Limites de juros: uma questão de ordem (a inconstitucionalidade da lei de reforma bancária) e publicado na Revista Jurídica da Escola Superior do Ministério Público do Estado de São Paulo, ano 2, n 3, jan./jun. 2002, p. 41 a 71, embora também seja adepto da corrente que entende não haver necessidade de regulamentaçāo do $\$ 3^{\circ}$ do art. 192 da Constituiçāo Federal, no que tange aos juros, dá uma outra razão para isso. Com efeito, pondera (artigo citado, p. 54-55): "3.1.2 Do artigo 25 da ADCT/88 - Mas nāo é só: ainda que admitida a competência do Conselho Monetário Nacional para limitar a taxa de juros - que passou a ser livre - a partir da vigência da Lei $n^{\circ}$ 4.595/64 (art. $4^{\circ}$, IX), o artigo 25 do atual ADCT revogou de forma expressa todos os dispositivos legais que atribuiam ou delegavam ao poder Executivo competência assinalada pela Constituiçâao ao Congresso Nacional. Manoel Gonçalves Ferreira Filho, com acuidade, observa: 'Revogaçāo de delegaçōes. É curioso este artigo. A Constituição anterior, inclusive com a redaçāo da Emenda n⿳亠 1/69 (art. 6º parágrafo único), proibia a qualquer Poder, portanto inclusive ao Legislativo, delegar atribuições ou competências a outro Poder, como o Executivo. Assim, se delegações houve, eram elas inconstitucionais, e, assim o caso não era de revogação, e sim de anulaçāo." Observação: o mencionado art. 25 do "Ato das Disposiçōes Constitucionais Transitórias" dispōe o seguinte: "Ficam revogados, a partir de cento e oitenta dias da promulgação da Constituição, sujeito este prazo a prorrogação por lei, todos os dispositivos legais que atribuam ou deleguem a órgão do Poder Executivo competência assinalada pela Constituição 
ou, então, escusas para que os bancos possam fazer o que bem entendem com seus clientes. ${ }^{10}$ Louvem-se, por fim, as corretas decisões que têm sido adotadas pelos nossos tribunais, notadamente no âmbito do Superior Tribunal de Justiça, ${ }^{11}$ cujos acórdāos têm maciçamente declarado que o Código do Consumidor aplica-se, sim, às relações bancárias. ${ }^{12}$

ao Congresso Nacional, especialmente no que tange a: $I$ - açāo normativa [...]" De qualquer forma, entendemos que houve, efetivamente, a repristinação do Decreto $n^{02} 22.626 / 33$, no que tange à taxa máxima de juros, até porque assim dispōe, como visto, a Carta Constitucional de 1988.

10 MAIS PRIVILÉGIOS: Do jornal Folha de S. Paulo, edição de 1-11-2002, p. B-2, extraímos a seguinte notícia, com a manchete: "EMPRÉSTIMOS - CMN decide que instituiçôes terão prioridade sobre funcionários - BANCO RECEBE ANTES DÍVIDA DE FALIDA - (Da Sucursal de Brasília) - Decisão tomada pelo CMN (Conselho Monetário Nacional) deu aos bancos prioridade no recebimento de dividas contraídas por empresas que tenham sua falência decretada. Os bancos terão prioridade até mesmo sobre o pagamento de direitos trabalhistas, que costumam ter preferência no caso de falências e concordatas. A medida se refere a empresas que tomem empréstimos nos bancos e entreguem, em troca, alguns de seus bens como garantia da operaçāo. Caso a empresa tenha a falência decretada, as garantias entregues aos bancos não vão entrar na massa falida. Massa falida é o nome dado aos bens que a empresa quebrada possui e que serão vendidos para que as dividas possam ser pagas. Essas dívidas, por sua vez, são pagas em uma determinada ordem, fixada por lei. Direitos trabalhistas estão no topo da lista de prioridades. O CMN permitiu que as garantias dadas pelas empresas fiquem fora da massa falida. Ou seja, os bancos poderão receber seu dinheiro antes dos empregados da companhia. A decisão foi tomada com base na Medida Provisória no 2.192, de 24 de agosto de 2001, que promoveu mudanças na legislação sobre o assunto. $O$ objetivo é dar aos bancos mais garantias de que não irão levar calote no caso de falência da empresa. $O$ diretor de Normas do BC, Sérgio Dardy, disse que, com isso, os riscos dessas operaçōes serão menores. Isso permitiria, em tese, que os bancos reduzam os juros sobre os financiamentos." Aguardemos que o Poder Judiciário aplique efetivamente a ordem estabelecida pela Lei de Falências, e não mais essa esdrúxula medida provisória, que afronta os mais comezinhos princípios dos Direitos Comercial e Trabalhista.

"Civil - Instituições financeiras. Código de Defesa do Consumidor. Aplicaçāo. Súmula nº 83 do STJ. Os bancos, como prestadores de serviços e fornecedores de produtos financeiros, estão sujeitos ao Código de Defesa do Consumidor. A questão da aplicação do Código de Defesa do Consumidor aos contratos financeiros suscitou algum inconformismo, a despeito da clareza com que houve o legislador na elaboração daquele diploma, especialmente na conceituaçāo contida no artigo $3^{\circ}$ e seus parágrafos, de modo a evidenciar sua abrangência sobre a atividade das instituiçôes bancárias, inseridas não apenas na definição de prestadoras de serviços, mas também na de fornecedora de produtos financeiros. Porém, nesta Corte está pacificado o entendimento da aplicação do Código de Defesa do Consumidor às instituiçōes financeiras. $\dot{E}$ de se conferirem os seguintes julgados: Resp. $n^{\circ}$ 323.986-RS, DJU de 1 '-10-2001, rel. Min. Nancy Andrighi; Resp. n²63.642-RS, DJU, de 20-8-2001, rel. Min. Direito; Resp. n־175.795-RS, DJU, de 10-5-1999, rel. Min. Waldemar Zveiter; Resp. n־57.974-RS, DJU de 29-5-1995, rel. Min. Ruy Rosado de Aguiar (STJ - AI no 470.716-RS, rel. Min. Antônio de Pádua Ribeiro) DJU de 29-10-2002, Seção 1, 445."

12 No tocante ao limite de juros, todavia, veja-se recente julgado do STJ, que afasta limitação de juros imposta a administradora de cartões de crédito (Fonte: STJ 22-10-02). Os ministros da Quarta Turma do Superior Tribunal de Justiça (STJ) asseguraram à Sudameris Administradora de Cartōes de Crédito e Serviços a qualidade de instituiçāo financeira e afastaram a limitaçāo de juros na cobrança de dívidas. A decisāo do STJ reformou acórdāo do TJ-RS, que, ao julgar ação revisional de débito por utilização de cartāo de crédito, havia restringido os juros cobrados pela administradora em $12 \%$ ao ano. A Sudameris ajuizou açāo contra a consumidora Eliane em outubro de 1997. Segundo alegou, a consumidora contraiu uma dívida, em maio do mesmo ano, no valor de $R \$ 1.858,32$, decorrente de aquisiçāo de bens e serviços, mediante utilização do cartāo Sudameris-Visa. De acordo com os cálculos da administradora, em 24-10-1997 o saldo devedor alcançava $\mathrm{R} \$ 2.128,97$, corrigido monetariamente e acrescido dos juros de mora de $1 \%$ ao mês e multa contratual de $10 \%$. A Sudameris pediu, ainda, a correçāo do valor conforme os índices adotados pelo Poder Judiciário até a data do efetivo pagamento. Eliane, por outro lado, pretendia obter a redução da dívida, bem como a declaraçāo de abusividade. 
Sem muito alarde, foi editada a Emenda Constitucional $n^{\circ}$ 40, de 29-5-2003. Assim, o artigo 192 da Constituiçāo Federal passou a ter a seguinte nova redaçāo: "O sistema financeiro nacional, estruturado de forma a promover o desenvolvimento equilibrado do País e a servir aos interesses da coletividade, em todas as partes que o compõem, abrangendo as cooperativas de crédito, será regulado por leis complementares que disporão, inclusive, sobre a participação do capital estrangeiro nas instituições que o integram. I - (Revogado). II - (Revogado). III - (Revogado) a) (Revogado) b) (Revogado) IV - (Revogado) V - (Revogado) VI - (Revogado) VII - (Revogado) VIII - (Revogado) $\$ 1^{\circ}-$ (Revogado) $\$ 2^{\circ}-$ (Revogado) $\$ 3^{\circ}-$ (Revogado)." Assim, caiu a limitação constitucional de juros de $12 \%$ ao ano. Era o que os banqueiros queriam.

Em didática palestra proferida no "II Congresso Paraibano de Direito do Consumidor", realizado em Campina Grande, em 12-10-2003, o ilustre Prof. Adalberto de Souza Pasqualotto, ao comentar a ADIN no $2.591-1$ em questão, em face da $2^{\mathrm{a}}$ parte do $\ 2^{\circ}$ do art. $3^{\circ}$ do Código de Defesa do Consumidor, ou seja, no sentido de excluir suas atividades das relaçōes de consumo, resumiu os seus principais argumentos, a saber: (a) a atividade bancária depende de lei complementar, conforme disposto no caput do art. 192 da Constituição Federal; ora, o CDC não é lei complementar, e, portanto, não poderia disciplinar matéria afeta ao sistema financeiro; (b) o dispositivo do CDC diz que estão sujeitos aos seus postulados os

Afirmou que a Sudameris vem cobrando valores excessivos, mediante capitalização mensal de juros remuneratórios, além de cobrar juros superiores a $12 \%$ ao ano. A primeira instância da Justiça gaúcha acolheu parcialinente o pedido da consumidora e, diante disso, a Sudameris apelou, sem obter sucesso. Para o TJ-RS, o advento da correção monetária igualou no mesmo patamar as instituiçōes financeiras e os demais agentes que nāo integram o Sistema Financeiro Nacional, "restando que os

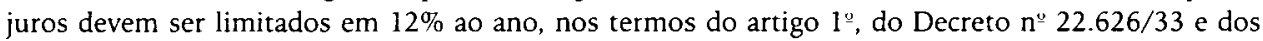
artigos 1.062 e 1.063 do Código Civil". Segundo o tribunal estadual, no caso em questāo, deve ser aplicada a legislaçāo infraconstitucional, proibitiva de juros superiores ao dobro da taxa legal. A administradora, então, recorreu ao STJ. Entre seus argumentos, apontou violação aos artigos $4^{\circ}$ da Lei $n^{m}$ 4.595/64 e 1.262 do Código Civil, tendo em vista que, tanto a Constituição Federal, a Lei de Usura e o Código Civil não se aplicariam ao contrato firmado com a consumidora. De acordo com a Sudameris, a legislaçāo pertinente confere com exclusividade ao Conselho Monetário Nacional a prerrogativa de dispor sobre os juros, sendo lícito pactuar como fizeram a administradora e a consumidora. Ao julgar recurso da Sudameris, o relator no STJ, ministro Aldir Passarinho Junior, apreciou, inicialmente, se a qualidade de instituiçāo financeira pode ser concedida ou não à administradora de cartōes de crédito. Segundo o relator, a abrangência da Lei $n^{\circ} 4.595 / 64$ não deixa dúvidas quanto à inclusāo da empresa entre aquelas equiparadas a instituiçōes financeiras, uma vez que atua no mercado como intermediária na busca de financiamento da compra do usuário do cartāo. Com relação à limitação dos juros, o relator esclareceu que com o advento da Lei $\mathrm{n}^{\prime \prime} 4.595 / 64$, disciplinando de forma especial sobre o Sistema Financeiro Nacional e suas instituiçōes, afastou-se a incidência da Lei da Usura, no tocante à limitação dos juros. Quem detém poderes normativos para limitar as taxas é o Conselho Monetário Nacional. $\mathrm{Na}$ conclusão de seu voto, seguido pelos demais integrantes da Quarta Turma, o relator acolheu o recurso da Sudameris. "As limitaçōes impostas pelo Decreto no $22.626 / 33$ não se aplicam às taxas de juros cobradas pelas instituiçōes bancárias ou financeiras em seus negócios jurídicos, cujas balizas encontram-se no contrato e regras do mercado, salvo as exceçōes legais (crédito rurai, industrial e comercial)" - Processo: Resp 456673. 
serviços remunerados, sendo certo que os serviços bancários não o são; (c) as principais operaçōes dos bancos são as de crédito, que não se encaixam nem na rubrica produto, nem na de serviço.

Em conclusão, portanto, diríamos que tanto o CDC como o referido "código de defesa do cliente bancário", do BACEN, embora tenham o mesmo desiderato, não pode o segundo substituir ao primeiro, que deve prevalecer, o que nada tem a ver com a disciplina do setor financeiro propriamente dito.

Parodiando a parábola de Cristo citada no pórtico do presente ensaio, dai ao $C D C$ o que é do CDC, e ao CDBC em conjunto com o SFN o que é do CDBC e do SFN! 